\title{
Heritable Pleiotropic Effects of the Nectarine Mutant from Peach
}

\author{
I-C Wen', W.B. Sherman, and K.E. Koch \\ Horticultural Sciences Department, University of Florida, Gainesville, FL 32611
}

Additional index words. Prunus persica, fruit size, fruit color, fruit sugars, fruit organic acids

\begin{abstract}
Peach-to-nectarine mutations are associated with broad pleiotropic effects. The present study addresses the heritability of nectarine-specific effects in three hybrid families. A comparison of peach and nectarine siblings showed that nectarine fruit were smaller (less fresh weight), rounder, darker, redder, and had higher levels of sugars and organic acids. These heritable characteristics are similar to effects of spontaneous peach-to-nectarine mutations described previously.
\end{abstract}

Peach-to-nectarine mutations are accompanied by broad pleiotropic effects (Wen et al., 1994) and are inherited as though controlled by a single recessive gene (Blake, 1932). The term pleiotropic is used because it is unlikely that so many quantitative fruit characters change with a peach to nectarine mutation or that so many characters could be closely linked to the nectarine gene in inheritance. The broad observations by Darwin (1893), De Candolle (1884), Downing (1845), Hedrick (1917), Hesse (1975), and Oberle and Nicholson (1953) include descriptions of nectarines as being smaller, firmer, redder, and sweeter than peaches and also as differing in other aspects of flavor and aroma. A thorough quantification of these pleiotropic effects accompanying peach-to-nectarine mutations is described by Wen et al. (1994). The present work extends these analyses to determine which traits are coinherited with the nectarine character in siblings from three hybrid families.

\section{Materials and Methods}

Sibling peach and nectarine seedlings were from three hybrid families designated $\mathrm{H}_{1}, \mathrm{H}_{2}$, and $\mathrm{H}_{3}$. Each family was derived by hybridizing an advanced nectarine selection with 'Flordaglo' peach (heterozygous for the nectarine character). The three hybrid families were Fla. $82-16 \mathrm{~N}$ x 'Flordaglo' $\left(\mathrm{H}_{1}\right)$, Fla. $84-23 \mathrm{~N}$ x 'Flordaglo' $\left(\mathrm{H}_{2}\right)$, and Fla. 84-16N x 'Flordaglo' $\left(\mathrm{H}_{3}\right)$. Characteristics of the Fla. $82-16 \mathrm{~N}$ and Fla. $84-23 \mathrm{~N}$ parents included a chilling requirement of 200 chill units (CUs), a fruit development period (FDP) of 105 days, and a mean fresh weight of 106 g/fruit. Fla. 84$16 \mathrm{~N}$ has a chilling requirement of $250 \mathrm{CUs}$, a FDP of 88 days, and a mean fresh weight of $100 \mathrm{~g} /$ fruit. 'Flordaglo' has a chilling requirementof 150 CUs, a FDP of 78 days, and ameanfresh weight of $94 \mathrm{~g} /$ fruit.

Hybrid seedlings for the three families were planted as part of a high-density fruiting nursery (Sherman et al., 1973). Each family was planted together, but seedlings segregated 1: 1 for peach and nectarine and were randomly distributed along the row as they were established 18 months before first fruiting in 1990. There were 178 fruiting seedlings in family $\mathrm{H}$, of which 90 were nectarine; 127 seedlings in $\mathrm{H}_{2}$, of which 56 were nectarine; and 38 seedlings in $\mathrm{H}$, of which 18 were nectarine.

Received for publication 19 Jan. 1995. Accepted for publication 14 Mar. 1995. University of Florida Agricultural Experiment Station Journal Series no. R04540. The cost of publishing this paper was defrayed in part by the payment of page charges. Under postal regulations, this paper therefore must be hereby marked advertisement solely to indicate this fact.

'Current address: Taiwan Agricultural Research Institute, 189 Chung-Cheng Road, Wo-feng 41301, Taichung, Taiwan.
Each seedling in the $\mathrm{H}_{1}, \mathrm{H}_{2}$, and $\mathrm{H}_{3}$ families was assessed for bloom and ripeness dates to calculate the estimated chilling requirement and FDP. The FDP was calculated as days from the date when $50 \%$ of the flower buds had opened to the date when fruit were judged ready for first commercial harvest. Blossom dates of the nursery seedlings were compared to those of selected cultivars to obtain estimates of their chilling requirements (Sherman et al., 1988). Fruit shape for each genotype was determined from five categories ranging from 1 (a pronounced protuberance at the fruit apex) to 5 (round). Three representative ripe fruit from each fruiting seedling in a high-density fruiting nursery (Sherman et al., 1973) were harvested to compare fruit size, shape, and color in 1990 and 199 1. Seedling trees were 2 ( 1990) and 3 (1991) years old and thinned to about the same leaf : fruit ratios. Fruit for these measurements were collected from every seedling in each progeny that fruited in 1990, and the same seedling was used if it fruited in 1991. Twenty random seedlings of each family were used to determine content of sugars and organic acids in the first year and the same seedlings were used if they fruited in the second year.

Fruit color was measured as in Wen et al. (1994) with a HunterLab D25 optical sensor standardized to a gray plate $(\mathrm{L}=51.37$, a $=54.64, \mathrm{~b}=59.20)$. Lightness was measured on the ' $\mathrm{L}$ ' scale, which ranges from 0 for black to 100 for white. The degree of redness was measured on the ' $a$ ' scale, which is positive for red and negative for green. The degree of yellowness was measured on the 'b' scale, which is positive for yellow and negative for blue. All color measurements were made on unwashed, unbrushed fruit and leaves, because no significant differences were found between brushed and unbrushed peaches (data not shown). Each fruit sample was measured at an equatorial line on sunlit and shaded sides. The Minolta ' $a$ ' and ' $b$ ' values were used to compute hue angle $\left(\tan ^{-1} \mathrm{~b} / \mathrm{a}\right)$, a parameter correlated with visual appearance of many foods (Clydesdale, 1978; Crassweller et al., 1991; Francis, 1952). The lower the value, the more red the hue is generally perceived to be.

Fruit soluble solids (soluble sugars and organic acids) were separated, identified, and quantified via high-performance liquid chromatography (HPLC) as described in Wen et al. (1994). Fruit flesh was sampled from the sunlit and shaded sides of each fruit and stored at -80C until analysis. Preliminary data (not shown) indicated that the sugar concentration from sunlit and shaded sides of fruit was similar; therefore, equal numbers of samples from each side were pooled for total fruit analyses. Frozen tissue (5 to $8 \mathrm{~g}$ ) was ground in liquid $\mathrm{N}$ and extracted for each measurement. Organic acids were also identified and quantified by HPLC as described by Campbell and Koch (1989) and Wen et al. (1994).

The least squares means statistical analysis was used for comparing unbalanced data. 


\section{Results and Discussion}

Estimated chilling requirement and fruit weight and fruit shape in families $\mathrm{H}_{1}, \mathrm{H}_{2}$, and $\mathrm{H}_{3}$ are presented for peach and nectarine siblings in 1990 and 1991 (Table 1). Nectarine and peach siblings had similar chilling requirements in the $\mathrm{H}_{2}$ and $\mathrm{H}_{3}$ families. The peach siblings had a higher chilling requirement in the $H_{1}$ family. This might indicate a different type of nectarine allele $\mathrm{m}$ the $\mathrm{H}$, family. At least three different nectarine alleles are postulated for the three types of ultrastructural surfaces found in nectarine fruit (Fogle and Faust, 1975).

Fruit size (fresh weight) was variable from nectarine (19 to 141 g) and peach (17 to $157 \mathrm{~g}$ ) siblings. However, the average nectarine weighed $73 \%$ as much as their peach siblings in the $\mathrm{H}_{1}, \mathrm{H}_{2}$ and $\mathrm{H}_{3}$ families. Size reduction in these nectarines relative to then peach siblings was less than that observed when fruit of direct peach-tonectarine mutants were compared to their peach progenitors (Oberle and Nicholson, 1953; Wen et al., 1994). Fruit of the nectarine sports in these previous studies were about 50\% smaller. A similar size difference was also observed by Williams and Brown (1956), who compared the average fruit weights of a random sample of nectarine varieties with a similar sample of peach varieties and found that nectarines averaged about half of the weight of peaches. The basis for a reduction to less than half the size in fruit of nectarine vs. peach siblings in the present work may depend on the number of genes directly involved. The hypothesis advanced by Hesse (1975) was that nectarines are phenotypes for a minor, nonlethal deficiency further characterized by including closely linked genes or polygenes that affect fruit size. If more than one gene is involved, then either the linkage between some genes for small fruit size and glabrousness has been reduced or breeders have increased the extent to which genes for larger fruit size are associated with the nectarine character compared with the pubescence gene. Alternatively, the primary differences between nectarines and peaches may be encoded by a single gene such as Ttg in
Arabidopsis (Larkin et al., 1994) or $R$ (Lloyd et al., 1992) in maize. Both have broad pleiotropic effects on pigment and hair formation. If so, then interactions between a nectarine gene and others affecting fruit size may have been altered. In either instance, there has been a consistent effort among breeders recently to increase fruit size in nectarines.

Nectarines were also rounder with smaller distal tips than peaches in all families in 1990 and 1991 (Table 1). The greater degree of roundness in nectarines than in peaches supports the observation by a number of peach breeders (unpublished) that round shape is an easier trait to obtain when breeding nectarines than peaches.

Fruit surface color on the sunlit side was contrasted for peach and nectarine siblings in three segregating families in 1990 and 1991 (Table 2). Nectarines were significantly darker (lower ' $L$ ' values) than peaches on the sunlit fruit side in every comparison except for the $\mathrm{H}_{3}$ family in 1991 . The ' $\mathrm{a}$ ' value on the sunlit surface indicates that, for every comparison (families and years), the peaches were more red (higher ' $a$ ' value) than nectarines. Peaches were significantly more yellow (higher ' $b$ ' value) on the sunlit surface than nectarines in every comparison of families and years. In contrast, the hue angle on the sunlit surfaces showed in every comparison (families and years) that nectarines had a greater degree of perceived redness (lower value) than peaches. The apparent contrast between the two measures of redness ('a' and hue angle) shows how important the ' $b$ ' (yellowness) is in determining the hue angle (perceived redness). The hue angle is derived from ' $a$ ' and ' $b$ ' values and is generally considered a more reliable indicator of perceived redness than ' $a$ ' alone (Crassweller et al., 1991).

Fruit surface color on the shaded side was compared for peaches and nectarines in three segregating families in 1990 and 1991 (Table 3). Nectarines were darker (lower ' $L$ ' value) on the shaded side compared to peaches in the three families for both years. This is consistent with darker nectarines than peaches on the sunlit side.

Table 1. Mean fruit weight and shape and estimated chilling units (CUs) of three families $\left(\mathrm{H}_{1}, \mathrm{H}_{2}\right.$, and $\left.\mathrm{H}_{3}\right)$ segregating 1 : 1 for peach $(\mathrm{P})$ and nectarine (N) for 2 years (1990 and 1991).

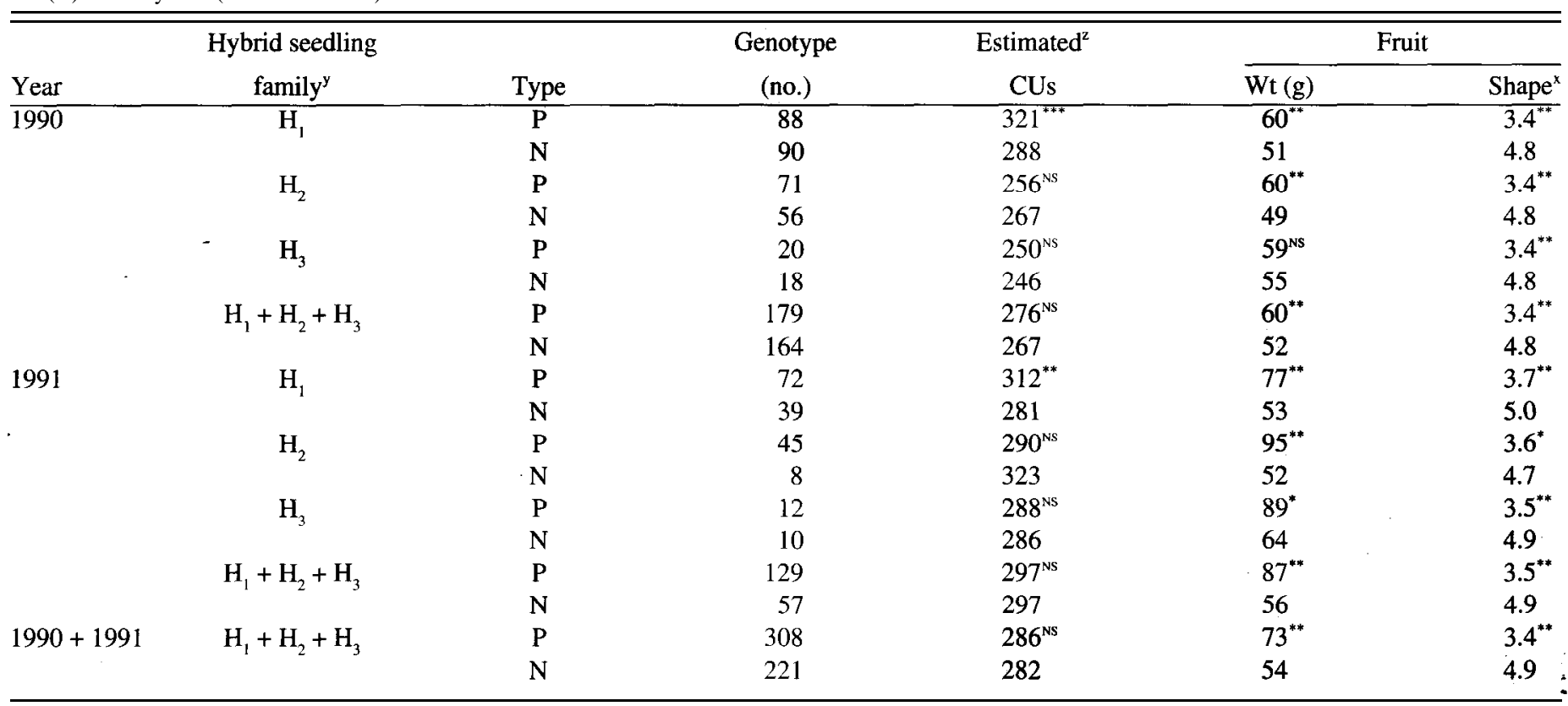

${ }^{2}$ Based on bloom date (Sherman et al., 1988).

${ }^{y} \mathrm{H}_{1}=$ Fla. $82-16 \mathrm{~N}$ x Flordaglo, $\mathrm{H}$,=Fla. 84-23N x Flordaglo, $\mathrm{H}_{3}=$ Fla. $84.16 \mathrm{~N}$ x Flordaglo.

'Rated $1=$ most pointed tip to $5=$ round at tip.

${ }^{\mathrm{Ns}}, *, * *, * * *$ Nonsignificant or significant at $10 \%, 5 \%$, and $1 \%$ levels, respectively. 


\begin{tabular}{|c|c|c|c|c|c|c|c|}
\hline \multirow[b]{2}{*}{ Year } & \multirow[b]{2}{*}{ Family ${ }^{z}$} & \multirow[b]{2}{*}{ Type } & \multirow{2}{*}{$\begin{array}{c}\text { Genotype } \\
\text { (no.) }\end{array}$} & \multicolumn{4}{|c|}{ Fruit color } \\
\hline & & & & $L^{y}$ & $a^{x}$ & $b^{w}$ & Hue angle \\
\hline \multirow[t]{8}{*}{1990} & \multirow[t]{2}{*}{$\mathrm{H}_{1}$} & $\mathrm{P}$ & 88 & $37.6^{* * * *}$ & $27.3^{* * * *}$ & $19.5^{* * *}$ & $33.9^{* * *}$ \\
\hline & & $\mathrm{N}$ & 90 & 31.9 & 24.8 & 10.6 & 22.8 \\
\hline & \multirow[t]{2}{*}{$\mathrm{II}_{2}$} & $\mathbf{P}$ & 71 & $36.0^{* * *}$ & $27.1^{* * * *}$ & $17.6^{* * *}$ & $32.2^{* * *}$ \\
\hline & & $\mathrm{N}$ & 56 & 31.9 & 24.2 & 10.0 & 21.8 \\
\hline & \multirow[t]{2}{*}{$\mathbf{H}_{3}$} & $\mathrm{P}$ & 20 & $35.2^{* * *}$ & $28.3^{* * * *}$ & $16.7^{* * *}$ & $30.1^{* * *}$ \\
\hline & & $\mathrm{N}$ & 18 & 31.5 & 22.7 & 9.8 & 23.3 \\
\hline & \multirow{2}{*}{$\mathrm{H}_{1}+\mathrm{H}_{2}+\mathrm{H}_{3}$} & $\mathrm{P}$ & 179 & $36.3^{* * *}$ & $27.5^{* * *}$ & $17.9^{* * *}$ & $32.1^{* * *}$ \\
\hline & & $\mathrm{N}$ & 164 & 31.8 & 23.9 & 10.2 & 22.6 \\
\hline \multirow[t]{8}{*}{1991} & \multirow{2}{*}{$\mathrm{H}_{1}$} & $\mathrm{P}$ & 72 & $36.7^{* * *}$ & $29.3^{* * *}$ & $19.4^{* * *}$ & $32.1^{* * *}$ \\
\hline & & $\mathrm{N}$ & 39 & 30.6 & 23.2 & 9.0 & 20.4 \\
\hline & \multirow[t]{2}{*}{$\mathrm{H}_{2}$} & $\mathrm{P}$ & 45 & $34.6^{* * *}$ & $28.2^{*}$ & $15.9^{* *}$ & $28.2^{* * *}$ \\
\hline & & $\mathrm{N}$ & 8 & 29.4 & 22.7 & 8.7 & 20.4 \\
\hline & \multirow{2}{*}{$\mathrm{H}_{3}$} & $\mathrm{P}$ & 12 & $35.7^{\mathrm{NS}}$ & $29.9^{* *}$ & $16.1^{* *}$ & $27.9^{*}$ \\
\hline & & $\mathrm{N}$ & 10 & 32.0 & 24.0 & 10.5 & 23.3 \\
\hline & \multirow{2}{*}{$\mathrm{H}_{1}+\mathrm{H}_{2}+\mathrm{H}_{3}$} & $\mathbf{P}$ & 129 & $35.7^{* * *}$ & $29.1^{* * *}$ & $17.1^{* * *}$ & $29.4^{* * *}$ \\
\hline & & $\mathrm{N}$ & 57 & 30.6 & 23.3 & 9.4 & 21.4 \\
\hline \multirow[t]{2}{*}{$1990+1991$} & \multirow[t]{2}{*}{$\mathrm{H}_{1}+\mathrm{H}_{2}+\mathrm{H}_{3}$} & $P$ & 308 & $36.0^{* * *}$ & $28.3^{* * *}$ & $17.5^{* * *}$ & $30.8^{* * *}$ \\
\hline & & $\mathbf{N}$ & 221 & 31.2 & 23.6 & 9.8 & 22.0 \\
\hline
\end{tabular}

${ }^{\overline{2}} \mathrm{H}_{1}=$ Fla. 82-16N x Flordaglo, $\mathrm{H}_{2}=$ Fla. 84-23N x Plordaglo, and $\mathrm{H}_{3}=$ Fla. 84-16N x Flordaglo.

'The lower the value, the darker the fruit.

The higher the value, the more red the fruit.

"The higher the value, the more yellow the fruit.

"Hue angle is the angle formed by plotting the $\mathrm{a}$ and $\mathrm{b}$ values and drawing a line through the origin. The lower the value, the more visually perceived the redness.

ss $, * * *, * * *$ Nonsignificant or significant at the $10 \%, 5 \%$, and $1 \%$ levels, respectively.

There was yearly variation for ' $a$ ' values on the shaded fruit side between peach and nectarine siblings. The shaded fruit side of nectarines in 1990 was more red (higher 'a' value) than their peach siblings but not in 1991. In contrast, the sunlit side of nectarines had lower 'a' values (less red) than peaches in every family and year. Peaches were more yellow (higher ' $b$ ' values) on the shaded side of the fruit than their nectarine siblings in the three families during both years. This is consistent with ' $b$ ' values found for the sunlit sides of the fruit. In general, the hue angle on the shaded fruit side also indicated that nectarines had a greater degree of perceived

Table 3. Surface color on the shaded sides of fruit from three families segregating for peach and nectarine for 2 years (1990 and 1991 ).

\begin{tabular}{|c|c|c|c|c|c|c|c|}
\hline \multirow[b]{2}{*}{ Year } & \multirow[b]{2}{*}{ Family $^{z}$} & \multirow[b]{2}{*}{ Type } & \multirow{2}{*}{$\begin{array}{c}\text { Genotype } \\
\text { (no.) }\end{array}$} & \multicolumn{4}{|c|}{ Fruit color } \\
\hline & & & & $\mathrm{L}^{y}$ & $a^{x}$ & $b^{w}$ & Hue angle ${ }^{v}$ \\
\hline \multirow[t]{8}{*}{1990} & \multirow{2}{*}{$\mathrm{H}_{1}$} & $\mathrm{P}$ & 88 & $55.0^{\text {hA^ }}$ & $27.5^{\circ}$ & $36.6^{+44}$ & $51.9^{9+4+}$ \\
\hline & & $\mathrm{N}$ & 90 & 45.8 & 29.4 & 24.6 & 40.5 \\
\hline & \multirow{2}{*}{$\mathbf{H}_{2}$} & $P$ & 71 & $56.2^{* * *}$ & $24.8^{* * *}$ & $36.6^{* * *}$ & $55.2^{* * *}$ \\
\hline & & $\mathrm{N}$ & 56 & 46.7 & 28.8 & 25.1 & 40.9 \\
\hline & \multirow{2}{*}{$\mathrm{H}_{3}$} & $\mathrm{P}$ & 20 & $56.5^{* * *}$ & $25.3^{* * *}$ & $35.2^{* * *}$ & $54.7^{* * *}$ \\
\hline & & $\mathrm{N}$ & 18 & 43.3 & 31.0 & 24.3 & 38.1 \\
\hline & \multirow{2}{*}{$\mathrm{H}_{1}+\mathrm{H}_{2}+\mathrm{H}_{3}$} & $\mathrm{P}$ & 179 & $55.9^{* * *}$ & $25.9^{* * *}$ & $36.2^{* * *}$ & $53.9^{* * *}$ \\
\hline & & $\mathrm{N}$ & 164 & 45.3 & 29.7 & 24.7 & 39.8 \\
\hline \multirow[t]{8}{*}{1991} & \multirow[t]{2}{*}{$\mathrm{H}_{1}$} & $\mathrm{P}$ & 72 & $53.2^{* * * *}$ & $30.3^{\mathrm{NS}}$ & $34.8^{* * *}$ & $47.5^{* * *}$ \\
\hline & & $\mathrm{N}$ & 39 & 40.3 & 29.8 & 20.0 & 32.8 \\
\hline & \multirow[t]{2}{*}{$\mathrm{H}_{2}$} & $\mathrm{P}$ & 45 & $52.0^{* * * *}$ & $33.0^{\mathrm{NS}}$ & $32.1^{* * *}$ & $42.3^{* * *}$ \\
\hline & & $\mathrm{N}$ & 8 & 42.4 & 31.9 & 21.7 & 32.6 \\
\hline & \multirow[t]{2}{*}{$\mathrm{H}_{3}$} & $\mathrm{P}$ & 12 & $55.4^{* * *}$ & $31.4^{\mathrm{NS}}$ & $31.4^{* *}$ & $45.9^{\mathrm{Ns}}$ \\
\hline & & $\mathrm{N}$ & 10 & 42.9 & 29.4 & 24.3 & 38.9 \\
\hline & \multirow{2}{*}{$\mathrm{H}_{1}+\mathrm{H}_{2}+\mathrm{H}_{3}$} & $\mathrm{P}$ & 129 & $53.5^{* * *}$ & $31.6^{\mathrm{NS}}$ & $32.8^{* *}$ & $45.2^{* * *}$ \\
\hline & & $\mathrm{N}$ & 57 & 41.9 & 30.4 & 22.0 & 34.7 \\
\hline \multirow{2}{*}{\multicolumn{2}{|c|}{$1990+1991 \mathrm{H}_{1}+\mathrm{H}_{2}+\mathrm{H}_{3}$}} & $\mathrm{P}$ & 308 & $54.7^{* * *}$ & $28.7^{\mathrm{NS}}$ & $34.5^{* * *}$ & $49.6^{* * *}$ \\
\hline & & $\mathrm{N}$ & 221 & 43.6 & 30.0 & 23.3 & 37.3 \\
\hline
\end{tabular}

${ }^{\overline{2}} \mathrm{H}_{1}=$ Fla. $82-16 \mathrm{~N}$ x Flordaglo, $\mathrm{H}_{2}=$ Fla. $84.23 \mathrm{~N}$ x Flordaglo, and $\mathrm{H}_{3}=$ Fla. $84-16 \mathrm{~N}$ x Flordaglo.

'The lower the value, the darker the fruit.

"The higher the value, the more red the fruit.

"The higher the value, the more yellow the fruit.

"Hue angle is formed by plotting the a and $\mathrm{b}$ values and drawing a line through the origin. The lower the value, the more visually perceived the redness.

ss, $* * *, * * *, N o n s i g n i f i c a n t$ or significant at the $10 \%, 5 \%$, and $1 \%$ levels, respectively. 
redness (lower values) than peach siblings. The only exception was the lack of statistical significance for the $1991 \mathrm{H}_{3}$ family, however the trend for the mean agreed with those of other families and data from the sunlit sides of fruit. These trends and differences in ' $L$ ', ' $a$ ', ' $b$ ', and hue angle support the observation that it is easier to breed for red color in nectarines than peaches (W. Sherman, unpublished data).

When shaded and sunlit sides of peaches and nectarines are contrasted for overall 'L', 'a', 'b', and hue angle values, the shaded sides of fruit clearly had higher values for ' $L$ ' , ' $b$ ' , and hue angle, indicating that the shaded sides were brighter (less dark), more yellow, and less red than the sunlit sides. In general, the shaded sides of fruit also had higher 'a' values than the sunlit sides; thus, the perceived dark red color of the sunlit sides (hue angle) actually received a lower value for redness on the 'a' scale, possibly because of the darker surface (lower ' $L$ ' values). This is consistent with the observations of Crassweller et al. (1991) in apple. The apparent disparity between the 'a' value and the hue angle for measuring redness again indicates the importance of the ' $b$ ' value (yellowness) in measuring overall perceived redness (hue angle). The hue angle is also more consistent with visual appraisal and appears to be the most appropriate measure of red color on peaches and nectarines.

Sugar analysis of fruit from peach and nectarine seedlings (Table 4) showed that sucrose was the major sugar in peaches and nectarines, accounting for over $65 \%$ of the total sugar. In general, the sucrose level in nectarines was higher than that of peaches, although there were year and family variations (no such differences were evident in the $\mathrm{H}_{2}$ family during either year, for example). Glucose and fructose were present at about equal levels in peaches and nectarines. Although means for glucose concentrations in nectarines were higher than those in peaches, only the nectarines of the $\mathrm{H}_{1}$ family in 1990 had significantly higher glucose levels. There were no differences in fructose levels associated with peach vs. nectarine within families or years. Sorbitol was the least prevalent of the four sugars measured in peaches and nectarines and was generally present at lower levels in peaches during both years and when families were summed together. Overall, nectarines had higher total sugar levels (sucrose, glucose, fructose, and sorbitol) than peaches during both years and when data from families were combined, although differences were not apparent in the $\mathrm{H}_{2}$ family during either year or in the $\mathrm{H}_{3}$ family in 1991.

Total mean sugar concentration of fruit from peach and nectarine siblings in $\mathrm{H}_{1}$ and $\mathrm{H}_{3}$ families differed to about the same degree as those measured in the Fla. M3-1 peach compared to its nectarine mutant, Fla. M3-1N (Wen et al., 1994). Nectarines generally had higher concentrations of sugars than their peach counterparts.

Organic acid composition of fruit from peach and nectarine genotypes in the $\mathrm{H}_{1}, \mathrm{H}_{2}$, and $\mathrm{H}_{3}$ families for 1990 and 1991 is presented in Table 5. Malic was the predominant organic acid in fruit of peach and nectarine siblings in 1990 and 1991. Nectarines had or exhibited a trend for higher malic acid levels than peaches in both years. Similarly, nectarines had higher levels of citric acid than peaches. There was no apparent difference between succinic acid concentration in peaches and nectarines except in 1991, when nectarines in $\mathrm{H}_{1}$ and $\mathrm{H}_{3}$ families had higher levels. No quinic acid or acetic acid was detected. Nectarines generally had higher total organic acid levels than their peach siblings, although this was shown only as trends in $\mathrm{H}_{2}$ and $\mathrm{H}_{3}$ families during 1990. Overall, analyses of fruit from sibling seedlings showed that nectarines had higher levels of citric, malic, succinic, and total organic acid than peaches. This was consistent with data on the organic acid content of the Fla. M3-1 peach and its nectarine mutant Fla. M3-1N.

The effects of seedling age on fruit quality were pronounced. Peaches and nectarines from 3-year-old seedlings were bigger, redder, and had higher sugar levels than fruit from 2-year-old seedlings when comparing 1990 and 1991 data.

\section{Literature Cited}

Blake, M.A. 1932. The J.H. Hale as a parent in peach crosses. Proc. Amer. Soc. Hort. Sci. 29:131-136.

Campbell, C.A. and K.E. Koch. 1989. Sugar/acid composition and development of sweet and tart carambola fruit. J. Amer. Soc. Hort. Sci.

Table 4. Fruit sugars of three families segregating for peach and nectarine for 2 years (1990 and 1991).

\begin{tabular}{|c|c|c|c|c|c|c|c|c|}
\hline \multirow[b]{2}{*}{ Year } & \multirow[b]{2}{*}{ Family $^{z}$} & \multirow[b]{2}{*}{ Type } & \multirow{2}{*}{$\begin{array}{c}\text { Genotype } \\
\text { (no.) }\end{array}$} & \multicolumn{5}{|c|}{ Sugar $\left(\mathrm{mg} \cdot \mathrm{g}^{-1}\right.$ fresh wt) } \\
\hline & & & & Sucrose & Glucose & Fructose & Sorbitol & Total $^{y}$ \\
\hline \multirow[t]{8}{*}{$\overline{1990}$} & \multirow[t]{2}{*}{$\overline{\mathbf{H}}_{1}$} & $\mathrm{P}$ & 20 & $55.6^{++4}$ & $1.0^{+4+}$ & $11.7^{\mathrm{NS}}$ & $4.5^{44}$ & $82.8^{* * *}$ \\
\hline & & $\mathrm{N}$ & 20 & 66.6 & 16.3 & 13.0 & 8.4 & 104.3 \\
\hline & \multirow[t]{2}{*}{$\mathbf{H}_{2}$} & $\mathbf{P}$ & 20 & $65.9^{\mathrm{NS}}$ & $9.6^{\mathrm{NS}}$ & $11.8^{\mathrm{NS}}$ & $7.7^{\mathrm{Ns}}$ & $94.6^{\mathrm{NS}}$ \\
\hline & & $\mathbf{N}$ & 20 & 72.2 & 9.8 & 11.7 & 7.3 & 101.2 \\
\hline & \multirow[t]{2}{*}{$\mathrm{H}_{3}$} & $P$ & 20 & $54.4^{*}$ & $12.6^{\mathrm{NS}}$ & $10.6^{\mathrm{NS}}$ & $3.9^{* *}$ & $81.5^{*}$ \\
\hline & & $\mathrm{N}$ & 18 & 62.6 & 13.2 & 10.8 & 6.7 & 93.3 \\
\hline & \multirow[t]{2}{*}{$\mathrm{H}_{1}+\mathrm{H}_{2}+\mathrm{H}_{3}$} & $P$ & 60 & $58.6^{* * *}$ & $10.9^{* *}$ & $11.4^{\mathrm{NS}}$ & $5.4^{* *}$ & $86.3^{* * *}$ \\
\hline & & $\mathrm{N}$ & 58 & 67.2 & 13.1 & 11.8 & 7.5 & 99.6 \\
\hline \multirow[t]{8}{*}{1991} & \multirow[t]{2}{*}{$\mathrm{H}_{1}$} & $\mathbf{P}$ & 20 & $78.6^{* * *}$ & $10.9^{\mathrm{NS}}$ & $13.3^{\mathrm{NS}}$ & $5.9^{* * *}$ & $108.7^{* * *}$ \\
\hline & & $\mathrm{N}$ & 9 & 99.5 & 13.2 & 13.2 & 12.2 & 138.1 \\
\hline & \multirow[t]{2}{*}{$\mathrm{H}_{2}$} & $\mathbf{P}$ & 15 & $87.6^{\mathrm{MS}}$ & $11.4^{\mathrm{NS}}$ & $12.6^{\mathrm{NS}}$ & $6.7^{\mathrm{NS}}$ & $118.3^{\mathrm{NS}}$ \\
\hline & & $\mathrm{N}$ & 5 & 86.0 & 13.3 & 12.4 & 10.1 & 121.8 \\
\hline & \multirow[t]{2}{*}{$\mathrm{H}_{3}$} & $P$ & 12 & $79.8^{\mathrm{NS}}$ & $8.9^{\mathrm{NS}}$ & $12.0^{\mathrm{Ns}}$ & $5.2^{\mathrm{NS}}$ & $105.9^{\mathrm{NS}}$ \\
\hline & & $\mathrm{N}$ & 8 & 86.7 & 8.0 & 11.6 & 7.2 & 113.5 \\
\hline & \multirow[t]{2}{*}{$\mathrm{H}_{1}+\mathrm{H}_{2}+\mathrm{H}_{3}$} & $\mathbf{P}$ & 47 & $82.0^{* *}$ & $10.4^{\mathrm{NS}}$ & $12.7^{\mathrm{NS}}$ & $5.9^{* * *}$ & $111.0^{* *}$ \\
\hline & & $\mathrm{N}$ & 22 & 90.7 & 11.5 & 12.4 & 9.8 & 125.4 \\
\hline \multirow[t]{2}{*}{$1990+1991$} & \multirow{2}{*}{$\mathrm{H}_{1}+\mathrm{H}_{2}+\mathrm{H}_{3}$} & $P$ & 107 & $70.3^{* * *}$ & $10.7^{* *}$ & $12.0^{\mathrm{NS}}$ & $5.6^{* * *}$ & $98.6^{* * *}$ \\
\hline & & $\mathrm{N}$ & 82 & 79.0 & 12.3 & 12.1 & 8.6 & 112.0 \\
\hline
\end{tabular}

${ }^{7} \mathrm{H}_{1}=$ Fla. 82-16N x Flordaglo, $\mathrm{H}_{2}=$ Fla. 84-23N x Flordaglo, and $\mathrm{H}_{3}=$ Fla. 84-16N x Flordaglo.

'Total of sucrose, glucose, fructose, and sorbitol.

Ns,*,*****Nonsignificant or significant at the $10 \%, 5 \%$, and $1 \%$ levels, respectively. 


\begin{tabular}{|c|c|c|c|c|c|c|c|}
\hline \multirow[b]{2}{*}{ Year } & \multirow[b]{2}{*}{ Family ${ }^{z}$} & \multirow[b]{2}{*}{ Type } & \multirow{2}{*}{$\begin{array}{c}\text { Genotype } \\
\text { (no.) }\end{array}$} & \multicolumn{4}{|c|}{ Fruit organic acids (mg. $\mathrm{g}^{-1}$ fresh wt) } \\
\hline & & & & Citric & Malic & Succinic & Total $^{y}$ \\
\hline \multirow[t]{8}{*}{1990} & \multirow[t]{2}{*}{$\mathrm{H}_{1}$} & $\mathrm{P}$ & 20 & $3.1^{* * *}$ & $5.0^{* * *}$ & $3.3^{\mathrm{NS}}$ & $11.4^{* * *}$ \\
\hline & & $\mathrm{N}$ & 20 & 4.9 & 6.9 & 3.5 & 15.5 \\
\hline & \multirow{2}{*}{$\mathrm{H}_{2}$} & $\mathbf{P}$ & 20 & $4.4^{\mathrm{NS}}$ & $5.9^{\mathrm{NS}}$ & $4.1^{\mathrm{NS}}$ & $14.5^{\mathrm{Ns}}$ \\
\hline & & $\mathrm{N}$ & 20 & 5.3 & 6.5 & 3.3 & 15.1 \\
\hline & \multirow[t]{2}{*}{$\mathrm{H}_{3}$} & $\mathbf{P}$ & 20 & $3.5^{*}$ & $5.2^{\mathrm{NS}}$ & $4.2^{\mathrm{NS}}$ & $12.9^{\text {Ns }}$ \\
\hline & & $\mathrm{N}$ & 18 & 4.7 & 5.9 & 4.0 & 14.6 \\
\hline & \multirow{2}{*}{$\mathrm{H}_{1}+\mathrm{H}_{2}+\mathrm{H}_{3}$} & $\mathbf{P}$ & 60 & $3.7^{* * *}$ & $5.3^{* * *}$ & $3.8^{\mathrm{NS}}$ & $12.9^{* * *}$ \\
\hline & & $\mathrm{N}$ & 58 & 5.0 & 6.4 & 3.6 & 15.1 \\
\hline \multirow[t]{8}{*}{1991} & \multirow[t]{2}{*}{$\mathrm{H}_{1}$} & P & 20 & $3.6^{* *}$ & $5.6^{* * *}$ & $2.8^{*}$ & $11.9^{* * *}$ \\
\hline & & $\mathrm{N}$ & 9 & 5.1 & 7.5 & 3.9 & 16.5 \\
\hline & \multirow[t]{2}{*}{$\mathrm{H}_{2}$} & $\mathbf{P}$ & 15 & $4.1^{*}$ & $5.9^{*}$ & $3.0^{\mathrm{Ns}}$ & $13.0^{*}$ \\
\hline & & $\mathrm{N}$ & 5 & 5.9 & 7.1 & 2.8 & 15.9 \\
\hline & \multirow{2}{*}{$\mathrm{H}_{3}$} & $\mathbf{P}$ & 12 & $3.9^{* * *}$ & $5.6^{* *}$ & $2.5^{* *}$ & $12.0^{* * *}$ \\
\hline & & $\mathrm{N}$ & 8 & 6.3 & 7.0 & 3.7 & 17.0 \\
\hline & \multirow[t]{2}{*}{$\mathrm{H}_{1}+\mathrm{H}_{2}+\mathrm{H}_{3}$} & $\mathbf{P}$ & 47 & $3.9^{* * *}$ & $5.7^{* * *}$ & $2.7^{* *}$ & $12.3^{* * * *}$ \\
\hline & & $\mathrm{N}$ & 22 & 5.8 & 7.2 & 3.5 & 16.5 \\
\hline \multirow[t]{2}{*}{$1990+1991$} & \multirow[t]{2}{*}{$\mathrm{H}_{1}+\mathrm{H}_{2}+\mathrm{H}_{3}$} & $\mathbf{P}$ & 107 & $3.8^{* * *}$ & $5.5^{* * *}$ & $3.3^{\mathrm{NS}}$ & $12.6^{* * *}$ \\
\hline & & $\mathbf{N}$ & 82 & 5.4 & 6.8 & 3.5 & 15.8 \\
\hline
\end{tabular}

${ }^{{ }^{2}} \mathrm{H}_{1}=$ Fla. 82-16N x Flordaglo, $\mathrm{H}_{2}=$ Fla. 84-23N x Flordaglo, and $\mathrm{H}_{3}=$ Fla. 84-16N x Flordaglo.

Total citric, malic, and succinic acids.

ss,$* * * * * *$ Nonsignificant or significant at the $10 \%, 5 \%$, and $1 \%$ levels, respectively.

114:455-457.

Clydesdale, F.M. 1978. Colorimetry-methodology and applications. CRC Critical Rev. Food Sci. Nutr. 10:243-301.

Crassweller, R.M., H.L. Braun, T.A. Baugher, G.M. Greene, and R.A. Hollendar. 1991. Color evaluations of Delicious strains. Fruit Var. J. 45(2): 114-120.

Darwin, C. 1893. The variation of animals and plants under domestication. D. Appleton and Co., New York.

De Candolle, A. 1884. Origin of cultivated plants. Kegan Paul, Trench \& Co., London.

Downing, A.J. 1845. The fruits and fruit trees of America. Wiley \& Putnam, London.

Fogle, H.W. and M. Faust. 1975. Ultrastructure of nectarine fruit surfaces. Proc. Amer. Soc. Hort. Sci. 100:74-77.

Francis, F.J. 1952. A method of measuring the skin color of apple. Proc. Amer. Soc. Hort. Sci. 60:213.

Hedrick, U.P. 1917. The peaches of New York. J.B. Lyon, Albany, N. Y. Hesse, C.O. 1975. Peaches, p. 306320. In: J. Janickand J.N. Moore (eds.). Advances in fruit breeding. Purdue Univ. Press, W. Lafayette, Ind.

Larkin, J.C., D.G. Oppenheimer, A.M. Lloyd, E.T. Paparazzi, and M.D. Marks. 1994. Roles of the Glabrous 1 and Transparent testa glabra genes in Arabidopsis trichome development. Plant Cell 6: 1065-1076. Lloyd, A.M., V. Walbot, and R.W. Davis. 1992. Arabidopsis and Nicotiana anthocyanin production activated by maize regulators $\mathrm{R}$ and $\mathrm{Cl}$. Science 258:1773-1775.

Oberle, G.D. and J.O. Nicholson. 1953. Implications suggested by a peach to nectarine sport. Proc. Amer. Soc. Hort. Sci. 62:323-326.

Sherman, W.B., P.M. Lyrene, N.F. Childers, F.G. Gmitter, and P.C. Andersen. 1988. Low-chill peach and nectarine cultivars for trial in Florida. Proc. Florida State Hort. Soc. 101:241-244.

Sherman, W.B., R.H. Sharpe, and J. Janick. 1973. The fruiting nursery: Ultra high density for evaluation of blueberry and peach seedlings. HortScience 8:170-172.

Sherman, W.B., R.H. Sharpe, and V.E. Prince. 1972. Two red leaf characters associated with early ripening peaches. HortScience 7:502503.

Wen, Ien-chi, K.E. Koch, and W.B. Sherman. 1994. Comparison of fruit and tree characters of two peaches and their nectarine mutants. J. Amer. Soc. Hort. Sci. 119:101-106.

Williams, W. and H.G. Brown. 1956. Genetic responses to selection in cultivated plants; gene frequencies in varieties of Prunuspersica. Proc. Royal Soc. Bot. 145:239-242. 